\title{
The Social Responsibility of the East African Writer
}

Speaking on the development of writing in East Africa at the University of Ife, Nigeria, in 1968, David Rubadiri said that the colonial experience enveloped everything and almost stifled any indigenous attempt at expression through the newly acquired language. If one passed through a secondary school in East Africa, he said, the best one came out with was an ability to write a composition or a letter in the best basic English and the best grammar. Rubadiri noted that when the East African writer started to write poems, his whole literary tradition had molded him to try to emulate the only literature he had come into contact with. "So people wrote like Keats and Wordsworth-on roses and sunsets and moonshine, and this sort of subject, all on a very personal and individual sort of basis," he said, adding, "They received encouragement from expatriate teachers, and even non-expatriate teachers, because this was the only kind of literary tradition with which all the people had been brought up."

However, there was a tradition which contradicted this colonial cultural oppression. Ngugi wa Thiong'o (James Ngugi) says that in African society,

art was functional; it was not, as it is in modern Europe, severed from the physical, social and religious needs of the community. Song, dance and music were an integral part of a community's wrestling with its environment, part and parcel of the needs and aspirations of the ordinary man. There was never, in any African society, the cult of the artist with its bohemian priests along the banks of Seine or Thames. Today the artist in Europe sees himself as an outsider, living in a kind of individual culture, and obeying only the laws of his imagination ... African Art, we can generally say, used to be oriented to the community. And because of its public nature, culture, in its broad as well as in the narrow sense, helped to weld society together.

Rubadiri and Ngugi have pinned down two elements that help explain the form and nature of modern East African literature. Ngugi himself was one of the earliest East African writers to struggle against the cultural-mental colonialism identified by Rubadiri. His first major work was The Black Hermit, a play produced with an international student cast for Uganda's independence celebrations in 1962. Remi, the protagonist, is an educated African from a small tribe who refuses to return to the village from the city. 
The people of the village need him back to fight their battles, especially against domination from the bigger tribes. The village elders go to the city to fetch him back, after saying a prayer to the gods. The pastor is also persuaded to fetch Remi back by his mother. Remi does not agree at first to be persuaded by either kind of tradition, religion and value system. Besides, he has an English lover in the city. He suddenly tells her that he is married; he has been married by tribal law to Thoni, his brother's widow. He used to love Thoni but she seemed to love his brother; so his marriage was not to his liking. Eventually, he does return, with a friend from another tribe, to bring the message of cooperative, non-tribalist living. In the process of making his public speech, he insults Thoni, who runs away and commits suicide. Too late, Remi realizes that Thoni had always loved him.

It is easy to fault The Black Hermit. There is a touch of melodrama in the ending: a love affair that goes wrong because the lovers do not talk to each other, suicide, a letter which explains everything too late. Ngugi himself has said that he thought at the time of the first performance that the biggest problem besetting the new East African countries was tribalism, but now he realizes that the problem is really monopoly capitalism, which took the form of first imperialism and now neocolonialism. Ngugi attempts to inject his later understanding into the published version of the play by getting one of the characters to talk about the muzzling of trade unions by the new African government and to question whether the land, the banks and the oil companies will be nationalized. These ideas are not fully developed in the play. Still, the play has considerable merits. Through it, Ngugi has brought the village onto the stage on which previously only European plays used to be performed, giving validity to precisely that portion of the East African experience that the writers had been almost forced to forget. The play presents a "total" picture of modern East Africa at the point of decolonization. Ngugi gives validity to life in the city and the village by using prose with jazzy rhythms for the city, and verse for the village scenes. The verse gives a sense of the ritualistic, "rooted" quality of life in the village, contrasted with the rootlessness of the city. The villagers use earthy imagery, such as,

Remi left a young wife.

And she, like a sapling in a drought-stricken land, Will also dry up in the heat of desolation.

In The Black Hermit, we see Ngugi's deep sense of social responsibility to East Africa and Africa as a whole. The play asks fundamental questions: What do we expect of our leaders? Can we ignore our past and cut ourselves off from it? What happens when leaders come out with large solutions but forget their own individual failings? What happens when they ig- 
nore human relationships? What is the relationship of the individual to society in modern Africa?

Ngugi was to deal with these questions in more depth in his novels. The first of these was originally entitled The Black Messiah and was subsequently published in 1965 as The River Between. In this novel, Ngugi deals with what the Nigerian critic Omalara Leslie calls the soft paw of colonialism: the division brought about by Christianity acting sometimes unconsciously but usually consciously in tandem with colonialism. European Christianity softened the people so that the imperial powers could rule with minimal resistance. It did so by persuading the colonized people that they were cultural and religious savages before the coming of the white colonizer and by making the people feel that they had to accept the status quo as God's will for man. Christianity was also linked up with education, for which there developed a hunger in Africa. Waiyaki tries to acquire an education which he can use to help his people, but the division brought by colonialism proves too great for him to bridge. The novel has the quality of a moral fable. In Weep Not Child, which was published earlier, Ngugi goes further in exploring the colonial history of Kenya by dealing with the Mau Mau movement, a guerrilla movement that did not have a parallel in Uganda or Tanganyika. Robert Ruark had characterized the Mau Mau movement in his novel Something of Value as savage and atavistic. Ngugi reverses this characterization and shows us the historical rationality behind the movement. He shows us that the white man stole the land from the Gikuyu, who had not only an economic but also a spiritual attachment to the land going back to the beginning of time. We see all the peaceful attempts to get back the land, failure, and then no alternative but guerrilla fighting. Although Ngugi makes us sympathetic to the Mau Mau movement, he also presents a fair picture of the white settlers whose interests were threatened. For example, he gives us an insight into Mr. Howlands, even when the settler tortures Ngotho, the real owner of the land. Ngugi writes essentially from the viewpoint of Njoroge, a young boy. The style suits the subject, having a Biblical simplicity for which Ngugi has been noted. This style has the limitation that it cannot show us the ideology of the Mau Mau movement or point the way ahead for Kenya, but it has the advantage of illustrating that one has to be taught to exploit or to accept exploitation.

Ngugi's third novel, A Grain of Wheat, has received recognition as one of the best novels to emerge from Africa. Ngugi wrote it while he was in England, while he could see the mother country from close quarters and acquire the perspective to crystallize his understanding of colonialism. This novel begins on the eve of independence and moves backwards and forwards in time because Ngugi is dealing with very complex questions. Not only does he want to show how Kenya gained its independence; also he wants to find out what happened to the souls of the people and to suggest that real inde- 
pendence will be attained through another process in which the scarred souls regain their wholeness. Thus the novel has not only a historical setting but also a psychological sub-text. Ngugi has been noted for being a messianic writer, and nearly all the characters in this novel, including the colonial officer, are motivated by idealism of some kind or other. This idealism leads to betrayal. One of the men betrayed is the executed leader Kihika. Kihika explains the ideology of Mau Mau to Mugo: "We do not kill just anybody ... We are not murderers. We are not hangmen-like Robson -killing men and women without cause or purpose ... We only hit back. You are struck on the left cheek. You turn the right cheek. One, two, three -sixty years. Then suddenly, it is always sudden, you say: I am not turning the other cheek any more ... a few shall die that the many may live."

But the people are betrayed by what Frantz Fanon calls the new underdeveloped middle class, willing to serve the outside masters as long as they get dividends. A Grain of Wheat, as the title suggests, implies that the way out is a peasant revolution, a continuation of the aborted Mau Mau movement. Thus no character in the novel is more important than the others and there is no hero, no hermit or messiah. It is the masses who are important, and in his radio play This Time Tomorrow, Ngugi gives a picture of the victims of neocolonialism. The play is about slum clearance in Nairobi. The people, including those who had fought for independence as Mau Mau, are kicked out of their homes, which are then destroyed. As the neocolonial reality has deepened and time itself seems to stand still, Ngugi's style has evolved away from Biblical simplicity. A recent story, A Mercedes Funeral, resembles the fiction of Gabriel Garcia Marquez in its "marvellous" reality, its gigantic exaggeration, and its black humor.

At independence, there appeared to be a convergence between what was said by the political leaders, the people and the writers. The writers have used these early ideals to express, on behalf of the people, a feeling of betrayal over what should have happened. In doing this, all East African writers face some problems. The first concerns language. There are several languages in East Africa, but most of these languages are spoken and understood by only a small group within the nation-a least, in Kenya and Uganda -and not the nation as a whole. So the writer may discover that he has no choice but to use the language imposed by the colonizer, English. His next problem is how he is to transmute his experience in order to make it relevant to the nation as a whole. The imperial powers had arbitrarily drawn borders on the map and thus lumped diverse groups of people together; how is the writer to deal with the ethnic group or race of his origin and yet be relevant to the nation as a whole? And in a foreign language which seems to be restrictive?

Okot p'Bitek took the form of the Acholi song and developed it into a tool he used simultaneously to describe Acholi life and to provide a per- 
spective for criticizing the post-independence period. In Song of Lawino, which he wrote first in Lwo and then in English, he uses the device of a "simple" village woman railing against her politician husband for blindly embracing the artifacts of modern western life while denying his spiritual and cultural roots:

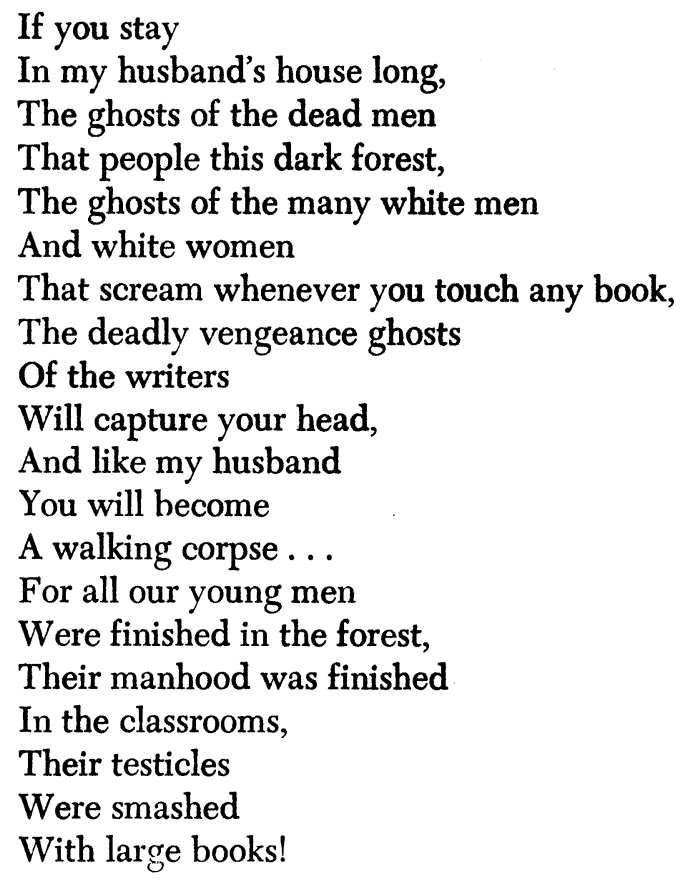

Lawino is not calling here for a physical return to the past. Neither is Lawino's voice identical with Okot's, though much of what she says has the endorsement of the author. Lawino recognizes the validity of cultural relativism, but her husband has a self-hatred induced by colonialism. She knows that if a person does not have roots, he cannot have anything else of value. Her criticism of her husband is that of the betrayed African peasantry:

Someone said

Independence falls like a buffalo

And the hunters

Rush to it with drawn knives,

Sharp, shining knives,

For carving the carcass.

And if your chest

Is small, bony and weak

They push you off 
And if your knife is blunt

You get the dung on your elbow

But come home empty-handed

And the dogs bark at you.

But Okot is doing more than just dealing with colonial/neocolonial exploitation on the level of ideas. He also tackles the chains of language, Christianity and time imposed by the colonizers. Lawino says,

Ocol tells me

Things I cannot understand,

He talks

About a certain man,

Jesus.

He says

The man was born

Long ago

In the country of white men.

He says

When Jesus was born

White men began

To count years:

From one, then it became ten,

Then one hundred

Then one thousand

And now it is

One thousand

Nine hundred

And sixty-six.

My husband says

Before this man was born

White men counted years backwards

Then it became

One thousand

Then one hundred

Then ten,

And when it became one

Then Jesus was born.

I cannot understand all this

I do not understand it at all! 
By using the form of the Acholi song and the device of a "simple" woman using "village" imagery, Okot makes a complete mockery of the colonizer's concepts of time and religion. He has created a non-English way of using English to break the cultural chains of colonialism. It is not surprising that Song of Lawino struck a chord in the hearts of many East Africans, and people could be heard discussing Lawino even in bars. Okello Oculi said that he was inspired by Okot to write his Orphan and Prostitute, both of which draw from his own Langi traditions. Oculi often invents English phrases and word-clusters by translating from his own language, while being more political than Okot: it is clear that Oculi is calling through his works for a complete peasant revolution. This is the challenge that faces his orphan and the prostitute, both of whom are at the crossroads.

Despite Okot, we are still haunted by ghosts. Much of the new writing emerging from East Africa is still written under the influence of the invisible colonial teachers. When the writers cannot forget these teachers, their prose emerges as explanatory, non-dramatic, static, dead. For example, in Mike Mwaura's novel, The Renegade, when the old man Ruhara is explaining his case against his son to the village court, he says,

Family problems should not be exposed; exposing them is like exposing nakedness. But when a man finds himself neglected by a son, and one he has toiled to raise at that, you can take it from me that there seems no refuge other than death. But then, if there are other souls to care for, one cannot resort to the rope so readily. Instead one lies prostrate on the horns of a dilemma and, as it were, the impaling points prick him more if he tries to turn. The prevalent question in his mind becomes: should I remain passive and leave everything on the unpredictable hands of destiny?

One cannot take issue here with the sentiments expressed by the old man, but one can say that the speech is long-winded and full of "correct" English expressions like "at that," "You can take it from me," "the horns of a dilemma," "as it were," and "the prevalent question." Mwaura is writing almost perfect English for that invisible English teacher and the effect is to slow the action to look at decorative images. But Mwaura's strong social concern breaks through this barrier. The novel deals with the hopes of a peasant who makes sacrifices to send his son to school in the hope that the son will then help uplift himself and the whole family. After all, the colonial authorities always held out education as bait. Unfortunately, Kunjuga is unable to make headway because the reality in Africa today is that schoolleavers have great expectations but usually cannot find employment. When he eventually gets a very low job in the city, he falls into "bad company" 
because it is inevitable that somebody with high expectations should try to live the good life. Kunjuga is betrayed by almost everybody and is unable to help his family, all of whom end up in trouble. His father decides to bring a case against him, which ends in humiliation for all concerned. The ending of the novel reflects a powerful use of language in contrast with the earlier example:

Now, as Ruhara continued massaging his swollen leg, tingles of pain creeping up his body every time he pressed it, he wondered why life had cheated him so, why he had tendered so much and reaped nothing, why life had not rewarded him for never shirking any of the many challenges that had confronted him, why ...?

As if to answer him, a wind came sweeping downhill, dust and withered leaves rising in its wake, its mad rush spelling nothing but famine. And up above, the sun continued its relentless march across the sky, its red-hot lips emitting nothing but fire on the panting earth.

In this passage, the description of nature reflects the physical and emotional state of Ruhara, a peasant; the wind, withered leaves and scorching sun give us a picture of a wasteland waiting for rain, of a people waiting for nourishment. Mike Mwaura may not clearly understand the reason why things have gone wrong but he performs the role of the African novelist described by Cyprian Ekwensi. Ekwensi says, "Now if the writer were accepted in African society he would be rather like the bird in the folk-tale that always appears on the wall and pipes a particular tune. When you hear that tune you know that there is tragedy somewhere; someone has died or something quite serious is happening. The bird disappears and within a moment you get the illumination of the bird's visit." Mike Mwaura is this kind of bird. So is Meja Mwangi, who, like Mwaura, deals with the dispossessed in a modern African city in his novel Kill Me Quick.

John Ruganda also falls victim to the invisible teachers in some of his plays, but in The Burdens he overcomes the burden of linguistic colonialism. The play is tightly constructed: it has only four characters and is in a very spare and taut language. In this play, post-independence society has begun to disintegrate; corruption, which began at the top, has now infected the whole society:

Tinka: The other day at the bus park.

Kaija: Yes?

Tinka: Two of them snatched a suitcase from a girl in high heels and sunglasses. Do you know what they found in it?

Kaija: Her shopping?

Tinka: The cold corpse of an infant. 
Kaija: In a suitcase?

Tinka: She was taking it to the father. A salesman in some oil company, she said. The crowd killed the two kondos on the spot.

Kaija: Served them right.

Here we can see a microcosm of the whole society. We see that the people no longer believe that they will receive justice from the machinery of the law, and they take the law into their own hands to mete out justice as they see fit. We see the "embourgeoisement" of the new elite; the detail of the oil company is significant, for this middle class is only a middleman between the people and the external corporations. The corpse of an infant in a suitcase suggests an image of a stillborn nation-or, rather, a nation that has been strangled at birth-in which cynicism has reached such a point that one can greet murder with "Served them right." Ruganda is using language not to draw attention to the language but to give us the illusion that we are looking directly at the grim reality.

East Africans are best able to write short plays in which the language must of necessity have punch. One of the most prolific of these is Kuldip Sondhi, an engineer by training. Encounter is a play about the Mau Mau movement which presents a case for the guerrillas by showing the necessity for such a movement in the freedom fight. In With Strings, Sondhi explores the implications of the Asian, i.e., Indian, presence in East Africa. The play deals with the problems raised when an Indian decides to marry an African. Both parties are upset. Mohan's father says, "With this kind of union you are breaking the laws of society. You will never be happy. You are an Indian and you must marry an Indian . . . The multi-racialism you talk of exists only in clubs. In real life the Indians, the Africans and Europeans are three different races . . . Inter-racial marriages may be things of the future, but at the moment people have hardly succeeded in breaking the simplest communal and religious barriers." The play ends with Mohan and Cynthia all alone on the stage, with the suggestion that they will get married and be all alone for some time. In a radio play, Sunil's Dilemma, Sondhi reverses the sexual relationship: he attacks the sexual taboo by suggesting a liaison between an African man and an Indian woman. Sunil, a mechanic, is a Kenyan citizen who loves the country and does not want to leave, while his wife, Devi, wants to leave because it is not safe for Asians in Kenya. Into their lives one night come two Africans, Kamau and Rashid, who claim to be policemen chasing thieves; they say that their car has broken down and they need Sunil's help. While Sunil is repairing the car, Rashid plants doubts in his mind as to whether Kamau, a womanizer, is having sexual intercourse with his wife back in the house. On Sunil's return to the house, he feels that his wife is no longer anxious to leave the country. The play is ambiguous right to the very end. Sondhi's purpose is to attack the sexual taboo imposed by 
colonialism prohibiting sexual relations between the men of the "lower" (i.e., conquered) race and women of the "higher" race. Since this taboo was imposed by colonialism, the play really attacks a whole series of colonial relationships.

Two other radio plays also deal with the Asian presence in East Africa. The first is Laban Erapu's Beyond the Line. Will Dr. Baasa, a cabinet minister, be willing to let his daughter Jenny marry Silva, a Goan? No, he is not, but, he says, is Silva's sister Brenda willing to marry his son? She is not. Within this framework, Erapu discusses other "Asian" problems. Dr. Baasa says that Brenda's father remained a British citizen until a year earlier; Brenda says that this was because he refused to bribe the officials. She also criticizes the government authorities for classing her as "Asian by race" in her citizenship papers. Dr. Baasa's answer is that there will always be cause for discrimination. Although he is well-meaning, clearly Dr. Baasa is bankrupt of any ideals or even ideas as to how the system inherited from the colonial rulers can be changed.

In Jagiit Singh's Sweet Scum of Freedom, Keval, a young Indian, comes to see Anna, a prostitute, for the last time, because he is leaving for England for higher studies. Why, Anna asks; after all, Keval's father is a citizen. Keval laughs bitterly. Yes, he says, his father is a third-class citizen. Keval himself has applied for citizenship three times but his applications have not been approved, while the minister keeps making public pronouncements that Asians must become citizens. Furthermore, first preference for admission into the medical school at the university is given to Africans. So he is going to England to study medicine, because his father wants him to study something that will help the family. But he would like to be a writer. When asked by Anna what he will write in his stories, he says,

\begin{abstract}
About you ... and about the wretchedness of being an Indian in Africa today. Always being the brown man out, the odd man, the foreigner, the Wahindi ... Little frightened fishes, swimming frantically in water made dirty by our commerce and trade; always afraid the big black minister will pull us out of the fishing pond and throw us away, far, far away to die without our dear commerce and trade. Yes, I'll write about how wretched and frightened we are today ... The British brought us here to trade and build railways because Africans couldn't do it. Dirt carriers we were of the British.
\end{abstract}

In reply, Anna says that it is the same for people like herself. Jagjit Singh is drawing a link between the prostitute and the Asian. Both are regarded as exploiters, but actually they are the scapegoats for the real exploiters who want to find an excuse for the lack of egalitarian development in the country. 
David Rubadiri has dealt with these ideas in his novel No Bride Price. Rubadiri's novel deals with the inevitable consequences of phony decolonization. The corruption of the greedy new bourgeoisie leads to a coup, signalled by European martial music. Like Singh, Rubadiri writes about prostitutes to draw attention to the real exploiters. Rubadiri is an internationally renowned poet, most famous for his much anthologized poem about the coming of colonialism to Uganda, "Stanley Meets Mutesa." Although his novel has a surface realism, it is actually a poetic puzzle full of symbols, metaphors and questions that the reader must work out. What is the image of twins running through the novel? What is the phoenix everyone keeps referring to? What is the significance of the early scene in which Miria tears off the new clothes Lombe has been wearing so proudly? One of the things the novel suggests is that Africans and Indians can pool together their similar communal experience and history of colonial exploitation to build for the future. I have taken up this theme in my novel, In a Brown Mantle, which deals with the Asian and, specifically, the Goan presence in East Africa and asks how the history of exploitation is to be ended. Like Rubadiri's novel, In a Brown Mantle has a surface realism but actually presents the reader with a series of riddles to be solved.

As the neocolonial reality has become grimmer under military dictatorship, so has Rubadiri's writing:

\author{
Tear it down \\ said the Messiah \\ Tear it down \\ it is an eye sore \\ tear it down \\ And plan it properly.
}

The reference here is to the decision to tear up the main street and broaden it for tanks to celebrate the anniversary of the coup. The poet goes on to make a bitter general comment on the significance of such military leaders:

\author{
It stood disgustingly ugly \\ this unsightly mound of earth \\ called AFRICA. \\ Like a sore thumb \\ they said \\ for everyone to see \\ as they circled \\ around moon rocks.
}




The demolition squad arrived,
lifted the old smelly hut,
and neatly dumped it again
into the Atlantic
making sure now
it was not dumped across it,
it might rise again
like a cancerous growth.

Rubadiri took the title of his novel from a poem by Henry Barlow, "My Newest Bride," which talks about the fight for independence as like that for a bride for whom a great bride price must be paid. Barlow does not romanticize independence. While he was a high official in the government and the slogan "building a nation" was being used, he wrote an ironic poem called "Building a Nation." In this poem, a permanent secretary and his chauffeur feel stomach pains, the former as a result of eating too much and the latter as a result of eating too little:

\author{
So two nation builders \\ Arrived home this evening \\ With terrible stomach pains \\ The result of building the nation- \\ Different ways.
}

There is the same wry irony in a poem, "The Pauper," by another Ugandan poet, Richard Ntiru:

Pauper, pauper, crouching in beautiful verandas

Of beautiful cities and beautiful people,

Tourists and I will take your snapshots

And your M.P. with a shining bald and triple chin

Will mourn your fate in a supplementary question at Question Time.

Because the social reality has become a nightmare but no literary censorship has been imposed, Ntiru does not have the inclination to write poems with echoes of Blake. Instead, we read,

Identification parades are a tricky affair where all the upturned faces smell of guilt.

Built around each profile is a halo of anonymous innocence intense but slowly dissolving into the smell of violent death.

Death: our last ritual blanket that some offer as casual presents 
resents abuse and denial by her agents. Silent rage, age and wisdom convulse this face like ridges on the Rwenzori Range

-Sage, what violence in a withered arm? Why the hell smell of death on your cotton head then? Or maybe Father fathered the Giant that ordered the blood flood?

Blood is cheaper than water. The Nile smells of guilt -guilt of knowledge of this proverb from source to mouth.

The Nile has been revered as the source of life but here it is seen as the accomplice of death.

One way of escaping the stranglehold of English is not to write in English at all. This option is only open to Tanzania, where one can write in Swahili and still speak to the nation at large. Ebrahim Hussein has chosen the path of a Swahili dramatist, probably following the example of President Nyerere, who has translated Shakespeare's Julius Caesar into Swahili. Hussein has published two Swahili plays, both of which are political, Kinjeketile and Mashetani. Kinjeketile deals with the famous Maji Maji uprising against the German colonialists at the beginning of the century. Kinjeketile is a seer who told the people that they would be protected by the water he was going to "baptize" them with. He really knows that the water does not have protective powers but believes that the people are all-powerful once they are united. However, things get out of hand. People come to believe that the water will really protect them from German bullets. Kinjeketile wants them to wait until they are ready, but he fails. The uprising takes place and the Africans lose. A German officer tries to persuade the seer to "recant," but he refuses; he becomes a true seer and says that a word has been born which will be passed on for generations until the word will be made a reality.

Mashetani is set between the Zanzibar revolution of 1964 and the socialist Arusha Declaration on the mainland of 1967. Juma and Kitaru are friends. One comes from the overthrown and now impoverished elite of Zanzibar and the other from the up-and-coming nouveaux riche of the mainland. Their friendship cannot be maintained because of political tension, which works its way through the medium of traditional Swahili beliefs in witchcraft and evil eye blended with modern psychology and the theories of socialism versus capitalism. While there is a tradition of political and patriotic Swahili epic verse, this play is a breakthrough in that it examines large issues in the personal lives and feelings of real individuals.

The socialist aspirations of Tanzania have had a literary influence on a well-known Ghanian novelist who has lived there for several years, Ayi Kwei Armah. He has published his fourth novel, Two Thousand Seasons, in East Africa. It is a story told in the collective voice, not "I" but "We": 
We are not a people of yesterday. Do they ask how many single seasons we have flowed from our beginnings till now? We shall point them to the proper beginning of their counting. On a clear night when the light of the moon has blighted the ancient woman and her seven children, on such a night tell them to go alone into the world. There, have them count first the one, then the seven, and after the seven all the other stars visible to their eyes alone.

This is the story of the whole black race, told with an African concept of time and communalism and bearing out the research of Chancellor Williams in The Destruction of Black Civilization. The people are determined to survive their betrayal by their leaders and the various imperialisms as a people.

I do not want to suggest that the social responsibility felt by nearly all East African writers leads to uniformity of style or grimness. Here is Maria Ssentamu of the village of Kalasanda, written about by Barbara Kimenye in two interlinked volumes of short stories:

[The Happy Bar] is the tin-roofed dwelling where Maria Ssentamu's sumptuous curves shake as she serves warm beer in thick, greasy glasses to the thirsty locals. Maria must surely weigh over fourteen stone. Nevertheless, she is by far the most seductive woman in the village, and she has a number of children to prove it.

Then there is Charles Mangua, whose rebellion took the following form:

Son of woman, that's me. I am a louse, a blinking louse and I am the jigger in your toe. I am a hungry jigger and I like to bite. I like to bite women-beautiful women. Women with tits that bounce. If you do not like the idea you are the type I am least interested in.

This is Dodge Kiunyu telling his erotic story in Son of Woman in the kind of "American slang" that would give those English teachers a fit! No wonder this work of fiction was one of the best-selling East African books. Although it appears to have no sense of social responsibility, in fact Son of Woman is the story of a man who will not play by the rules of "respectable," i.e., bourgeois society because it is selfish and inhuman.

And, of course, we cannot leave out Taban lo Liyong, one of the most prolific of East African writers. Taban entered the East African literary scene from the U.S. a decade ago, just before coming to The University of Iowa to do an M.F.A. He wrote a humorous, playful but serious lament of East Africa's literary barrenness: 
Ezekiel, Ezekiel, you saw the wheel: in the middle of the air. Will you help, Ezekiel, to resurrect our manly spirits to see the wheel of thought and imagination? Ezekiel Mphahlele (it sounds poetic: Mphahlele Ezekiel) teach us to write. Open our mouths. Else we choke with lumps of thought. Else we go migrating in search of inspiration to Mbari. Else we cut Ulli Beier into two and leave Nigeria with the legs.

We want more. But we do not even have any yet. Could we find an alchemist? An alchemist to change Moore, Gerald Moore, into a tribesman to give us another Mbari? Moore, will you teach us only to comment?

No longer can Taban or anyone else call East Africa barren in literature. The driving force behind the birth of its literature has been identified by Ngugi. He says, "Now there are only two tribes left in Africa: the 'haves' and the 'have-nots.' What goes for tribalism in Africa is really a form of civil war among the 'haves,' struggling for crumbs from the masters' tables. The masters sit in New York, London, Brussels, Paris, Bonn and Copenhagen; they are the owners of the oil companies, the mines, the banks, the breweries, the insurance institutions-all the moving levers of the economy. It is this situation that has given us A Man of the People, Song of Lawino, Voices in the Dark. It is this that is behind the critical self-appraisal and the despair in much of the current African literature." The struggle continues in life as in East African literature.

JOUNG HYUN-JONG / KOREA

\section{Poetry as a Possibility of Life}

Contemporary poetry has introduced freedom in the very body of the language. As a result, poetry appears as a phenomenon of freedom.

-Gaston Bachelard

Many Korean poets and critics agree that the traditional and remarkable quality of Korean poetry is what we call in Korean han. The meaning of the word han is so complex that it can hardly be translated into one 